\title{
ON THE ORIGIN \\ OF A GILDING METHOD \\ OF THE \\ BAGHDAD SILVERSMITHS
}

\section{Gerhard Eggert}

Conservation Department

Rheinisches Landesmuseum Bonn,

Germany

The evidence and arguments as to wether a galvanic gilding method observed in Baghdad is of ancient or modern origin are discussed. It is concluded that the technique is relatively recent. 


\section{INTRODUCTION}

Throughout the ages, artefacts have been made to look like gold using various techniques. Galvanic gilding was invented in the 19th century. Or was it only re-invented, as is persistently claimed both by sensationalists and by scientists, who argue that it might have been known for thousands of years? The basis for this speculation is a strange gilding method used by Baghdad silversmiths in 1938. Was it derived from ancient techniques or had it a more recent origin? This article examines the available evidence and the arguments of previous authors. The history of galvanic gilding is surveyed for comparison.

\section{BACKGROUND}

In 1938 Wilhelm König reported the excavation of a Parthian apparatus in Khujut Rabu'a [*] near Baghdad which 'consisted of a clay jar, a cylinder made

[*] Other transcriptions of the Arabic name in the literature are Khuyut Rabbou'a and Chujut Rabuah.

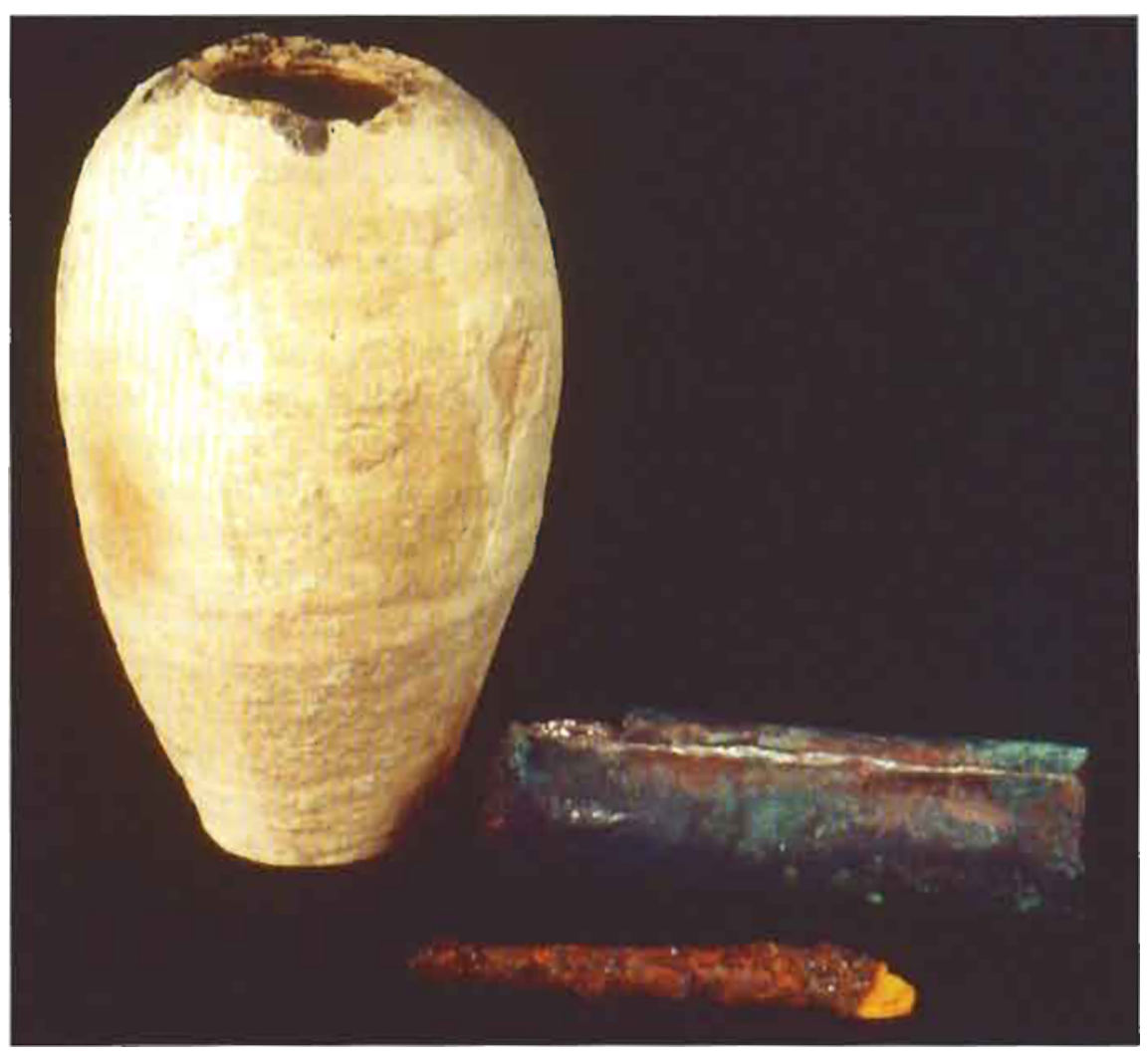

from copper sheet, and an iron rod' (Figure 1), [1] His interpretation of the find as a 2000 years old galvanic cell has often been cited, but is still a matter of discussion $[2,3,4]$. To lend more credibility to this claim, he added:

'However, it seems entirely possible that such an apparatus existed at that time. I might mention in this connection that even today the silversmiths in Baghdad use a primitive wet process for gold plating with the application of zinc, the origin of which cannot be determined'. [5]

But is it really true that the origin of the process cannot be determined? In his book on his stay in Iraq [6] he put it this way:

A primitive process of gold plating is still in use in Baghdad today on a secret [sic] electrical basis.

Probably it is older than one might think'.[5]

Details of the process, which combines a device acting as a source of electric current with a galvanic gilding bath in one unit, are obvious from an illustration in the 1938 paper (Figure 2). A porous clay jar allows electrolytic contact between the cyanide gold bath with the object to be gilded on the inside and the salt solution with the zinc on the outside. The zinc and the object are in electrical contact by means of a copper wire. Jansen and three coworkers [3] obtained excellent practical results with this method on silver cutlery some years ago.

Figure 1

Galvanic element or container for magic inscriptions? Parthian clay jar, copper cylinder, and iron rod found in Khujut Rabu'a. Iraq Museum Baghdad, IM 29,209 29,211 (Photo credit: by permission of Staatliche Museen zu BerlinPreußischer Kulturbesitz, Museum für Vor- und Frühgeschichte 


\section{DISCUSSION OF PREVIOUS ARGUMENTS IN FAVOUR OF A RECENT PROCESS}

Because of the use of zinc and a gold cyanide bath, one is tempted to assume a modern date for the process.

\section{a) Zinc}

It should not be forgotten that zinc was known in medieval times in China and India. There is even some evidence for the existence of elemental zinc (and not only brass) in antiquity $[7,8]$. Therefore, it is wrong to say 'zinc was certainly unknown in antiquity' [3] and from this to exclude categorically an ancient origin of the gilding method.

Nevertheless, there is so far no evidence for Parthian zinc. A different claim in the literature [9] is based on a very speculative translation of a letter of Pliny the Younger (Epistulae 10, 74). The small lump (glebulam, wrongly translated as 'piece of metal')

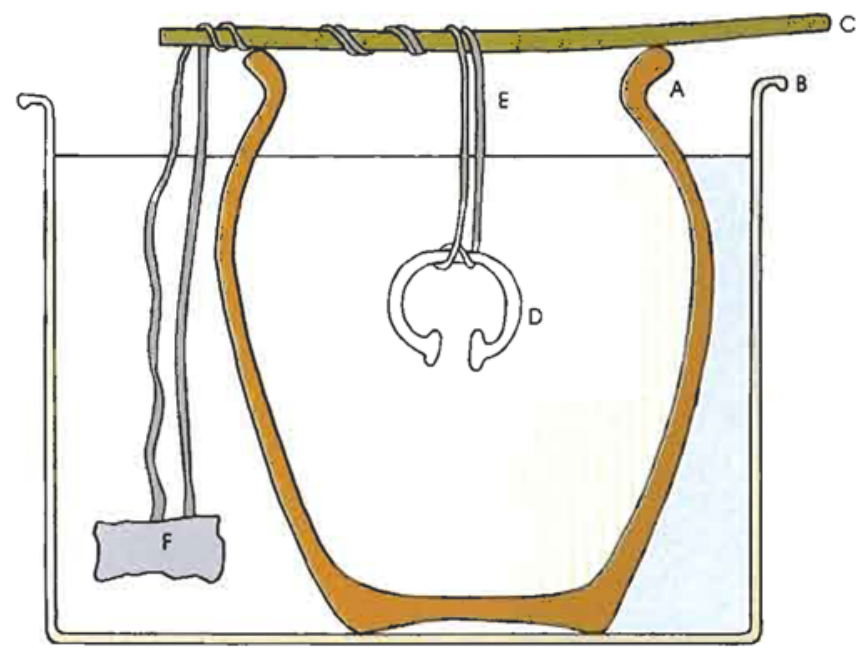

Figure 2

König's sketch [1] of the gilding method of the Baghdad silversmiths (coloured version: RLMB) with his explanations: A: Porous clay jar with gold cyanide solution; B: Cooking vessel with solution of common salt; $C$ : Rod for hanging; D: Object to be gilded; which was brought from a Parthian mine could be a gold nugget, an ore, or something else. Why must it be of zinc?

\section{b) Gold Cyanide Bath}

When discussing the patina of copper containers from Tell Asmar (2500 B.C.), König asked: 'Had copper containers probably been gold plated ...?' [5, p. 13]. The question proves that it is only a speculation and not an observation that the objects were gold plated (and if so, by which method). Nevertheless, some scientists, with only second or third hand knowledge of this claim, took it for granted that there were galvanic gilded objects dating from 2500 B.C. $[10,11]$. Despite such erroneous statements, there exist neither known ancient objects which support the claim of ancient electrolytic gilding, nor is there any written evidence.

Gold cyanides were discovered in the 18th century and were first applied in 1839 by Wright for electrolytic gold plating [12]. Nevertheless, Paszthory [2] has shown in a straightforward approach (using bitter almonds) that such solutions could easily have been produced millennia ago. The source of cyanide could be plants which contain amygdalin, a cyanogenic glucoside. Crushed kernels of bitter almond or sour cherry, a little brewer's yeast, water, warmth, time and, of course, gold dust are the only ingredients needed to obtain a 'very good electrolyzable solution', with which 'gleaming and pore-free gold layers were produced' [2, p. 35]. But as is always the case in experimental archaeology, successful experiments can only show a supposed ancient technique to be possible, but never by themselves that it was, in fact, applied. Other theories for obtaining gold plating baths (humic acids, rotten leather, gall) [13] were advanced in 1978 during the exhibition 'Sumer Assur Babylon' in Hildesheim, which presented the Khujut Rabu'a 'apparatus' [14]. Such hypotheses were never checked experimentally. Is the oxidation potential of gold really lowered by complexing agents in such solutions so that gold is dissolved and can it be successfully electroplated from them? 
All in all, an ancient origin for the gilding method of the Baghdad silversmiths is highly speculative, but so far cannot be ruled out completely on technical grounds. Its likelihood can only be judged by comparison with the alternative hypothesis of a modern origin.

\section{THE ORIGINS OF GALVANIC GILDING IN THE 19th CENTURY}

Compared with modern techniques the method observed in Baghdad in 1938 is something special, because it combines a current device (essentially a voltaic cell) and a cyanidic plating bath in one simple unit with only two electrodes. It has obviously two disadvantages: Firstly, the gold content in the bath depletes during plating and must be replenished; secondly, the contact of the electrolytes through the ceramic pores may lead to some contamination of the cyanide plating solution.

But is the Baghdad method unique? By consulting L.B. Hunt's 'Early History of Gold Plating' [15] this question can easily be answered - Figure 3 gives the edited version of Hunt's reproduction of an illustration of Wright's process 1839. For better comparison with Figure 2 the original figure ([15], p. 23) has been modified to a true cross-section drawing, the cross hatching replaced by colours, appropriate reference letters added, and only one front surface of the zinc sheet depicted. Hunt informs us in the caption to that figure:

'The first successful electroplating of a really coherent and adherent gold deposit was carried out by Dr John Wright at his house in the Bordesley district of Birmingham. An ordinary flowerpot containing the cyanide solution was placed in an outer vessel containing dilute sulphuric acid; the vase to be plated was connected by a wire to a sheet of zinc surrounding the porous cell and immersed in the dilute acid. Only a little later did the idea occur of separating the source of current from the plating bath, proposed indepen-dently by Thomas Mason of London and by Professor Jacobi of St Petersburg'.
Figure 3

Modified drawing of Wright's invention of 1839, explanations derived from Hunt's [15] caption:

A: Ordinary flowerpot containing a cyanide solution;

$B$ : Outer vessel containing dilute sulphuric acid; $C$ : (obviously metallic) rod; D: Object to be gilded; E: (metallic) wire;

F: sheet of zinc surrounding the porous cell

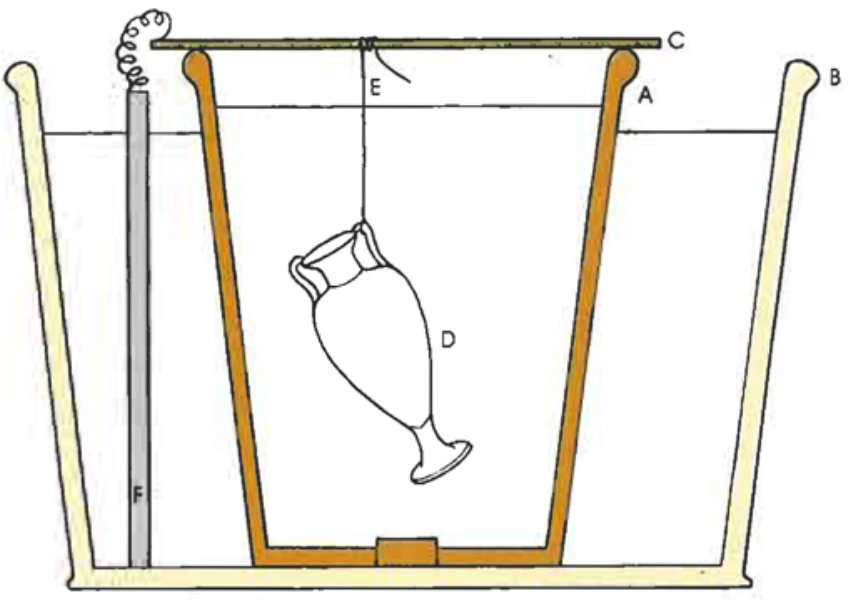

The characteristic combination of a current device and a plating bath in one cell is, therefore, no unique feature of the Baghdad method, but has also been used at the beginning of galvanic gold plating. Moreover, Wright's process is very, very similar, as is revealed by comparison of the figures and descriptions. Only a few details are different. The Baghdad process uses

1) a common salt solution, instead of dilute sulphuric acid, $\left[{ }^{*}\right]$

2) one wire for the connection of the object and the zinc, instead of different wires electrically connected by an obviously metallic bar on top of the flowerpot,

3) an unspecified 'zinc pole', instead of a cylindrical zinc sheet surrounding the flowerpot.

[*] By the way, in 1800 Allessandro Volta also used a common salt solution in his $\mathrm{Zn} / \mathrm{Ag}$-elements, bur later switched to dil. sulphuric acid. 
Wright's new process was purchased by the Elkingtons. They included it in their patent specification already filed on March 25th, 1840. In B.P. 8447, 'G.R. \& H. Elkington's Improvements in Coating, Covering, or Plating certain Metals' it is stated:

$\therefore$ is poured a solution of chloride of sodium or other exciting fluid; into this a cylinder of zinc is immersed, with a wire of copper soldered to it and made to bend over and dip into the inner vessel ...' (p. 5, line 2-5).

Earlier in the patent claim (p. 4., line 32/33), they state that galvanic currents can be produced by 'contact with a bar of metallic zinc'. All three apparent differences of the Baghdad method mentioned above are in fact contained in the Elkingtons' specification. The identity of the Baghdad method and the process described in the Elkington patent has apparently not been noticed by all who discussed the former process.

The only rational explanation is that the knowledge of the Elkingtons' patent diffused to Baghdad in some way, but not that of further improvements. Therefore, it was used unchanged in the bazaar of Baghdad nearly 100 years after its invention in Birmingham.

\section{CONCLUSIONS}

There are no literary sources or gilded objects which prove ancient knowledge of galvanic gilding. The gilding method of the Baghdad silversmiths is identical to the invention of B.P. 8447 , filed in 1840 . Therefore, there is no reason to postulate that this process is a relic of ancient knowledge.

Those who spoke of a modern origin of the process, because zinc and gold cyanide could in no way be ancient, came to the right conclusion, but for the wrong reasons.

\section{REFERENCES}

1. W. König: 'Ein galvanisches Element aus der Partherzeit?' Forschungen und Fortschritte, 14(1), $8-9,1938$
2. E. Paszthory: 'Stromerzeugung oder Magie', $A n-$ tike Welt, 16(1), 3-12, 1985. (Engl. Version: 'Electricity Generation or Magic? The Analysis of an Unusual Group of Finds from Mesopotamia', MASCA Research Papers in Science and Archaeology, 6, 31-38, 1989

3. W. Jansen, H. Fickenfrerichs, R. Peper \& B. Flintjer: 'Die Batterie der Parther und das Vergolden der Bagdader Goldschmiede', Part 1, CLB 38(10), 528-533, 1987; Part 2, CLB, 38(11) 586-592, 1987; Part 3, CLB, 44(3), 128-133, 1993

4. G. Eggert, "The Enigma of the "Battery of Baghdad"', 7th European Skeptics Conference, May 4-7th, 1935, Roßdorf (Germany), in print

5. For the unabridged English translations of [1] and [6] cited here see G. Dubpernell: 'Evidence of the Use of Primitive Batteries in Antiquity' in: G. Dubpernell \& J.H. Westbrook (Eds.): 'Selected Topics in the History of Electrochemistry', The Electrochemical Society, pp. 8-15, 1978

6. W. König: 'Neun Jahre Irak', Rudolf M. Rohrer Verlag, pp. 166-168, 1940

7. P.T. Craddock(Ed.): '2000 Years of Zinc and Brass', British Museum Occ. Paper No. 50, 1990

8. T. Rehren: 'A Roman Zinc Tabula from Bern, Switzerland', International Symposium on $A r$ chaeometry 94, Ankara, submitted for publication

9. M.Yu. Treister: 'About the Early Production of Metallic Zinc in Parthia', Bulletin of the Metals Museum, 15, 33-40, October 1990

10. J.O.M. Bockris \& A.K.N. Reddy: 'Modern Electrochemistry II', 3rd print., Plenum Press, note on p. 1265,1977

11. C. Reuber: 'Batterie-Geschichte(n)', Elektronik Journal, 9/89, 52-53, 1989

12. G. Williams: 'The Cyanides of Gold. The History of their Key Role in Electroplating', Gold Bull., 11(2), 56-59, 1978

13. G. Kirchner (Ed.): 'Reportagen aus der' Alten Welt', Fischer Taschenbuch, p. 103, 1978

14. Catalogue 'Sumer Assur Babylon', Verlag P. v. Zabern, No. 182, 1978

15. L.B. Hunt: 'The Early History of Gold Plating', Gold Bull., 6(1), 16-27, 1973 